\title{
Rumen Motility During Induced Hyper- and Hypocalcaemia
}

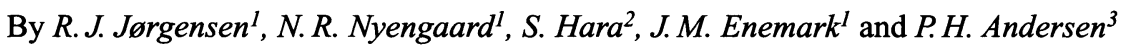

${ }^{1}$ Cattle Research Group and ${ }^{3}$ Surgery, Department of Clinical Studies, The Royal Veterinary and Agricultural University, Frederiksberg, Denmark, and ${ }^{2}$ Department of Veterinary Surgery, Faculty of Agriculture, Iwate University, Morioka, Iwate, Japan.

\begin{abstract}
Jørgensen RJ, Nyengaard NN, Hara S, Enemark JM, Andersen PH: Rumen motility during induced hyper- and hypocalcaemia. Acta vet. Scand. 1998, 39, 331-338. - Rumen motility was recorded on an experimental cow by means of telemetric signal transfer from strain gauge force transducers fixed surgically on the peritoneal surface of the rumen wall in the left flank. The normocalcaemic cow was given a standard milk fever treatment with calcium borogluconate $(400 \mathrm{ml}$ with $14 \mathrm{mg} \mathrm{Ca} / \mathrm{ml})$ intravenously. Transient clinical signs were: decreased rumination, muscle ticks, salivation and a heart rate reduction of $20 \%$. Rectal temperature remained unaltered. Frequency of rumen contractions was reduced up to $40 \%$ whereas amplitude of contractions did not deviate from baseline values. Hypocalcaemia was induced in a second experiment by iv infusion of Na2EDTA. At $0.60 \mathrm{mmol} / 1$ ionized blood calcium periods of no motility were recorded whereas inactivity of rumen activity was persistent at $0.55 \mathrm{mmol} / \mathrm{l}$ ionized blood calcium. The cow went down at $0.45-0.48 \mathrm{mmol} / \mathrm{l}$ ionized blood calcium at which point the heart rate was increased by $40 \%$. The high sensitivity of the method employed allowed the conclusion that already at a concentration of ionized blood calcium at $1.0 \mathrm{mmol} / \mathrm{l}$ both frequency and amplitude of rumen contractions decreased rapidly although eating behaviour and rumination appeared unaffected during the short term observation periods. Implications of this finding towards health and production in transition cows are discussed.
\end{abstract}

ionized blood calcium; EDTA-infusion; telemetric measurement.

\section{Introduction}

Calcium is a mineral of great importance in dairy herds, where $5 \%-10 \%$ of dairy cows develop clinical signs of periparturient hypocalcaemia, known as milk fever. The hypocalcaemic state develops as an imbalance between inflow and outflow from the extracellular calcium pool (Rosol et al. 1995). An additional, but unknown, number of cows develops periparturient subclinical hypocalcaemia. Hypercalcaemia, on the other hand, occurs only as an iatrogenic phenomenon following the intravenous treatment of hypocalcaemic cows with calcium salts (Radostitis et al. 1994).
Gastrointestinal motility is altered during various infections and metabolic diseases (Navarre $\&$ Roussel 1996). In the transition period, gastrointestinal function in cows is of particular interest for the maintenance of optimal appetite and the prevention of common diseases ( $R a$ dostitis et al. 1994). The neuro-muscular transmission in hypocalcaemic dairy cows is severely decreased as in other mammals (Bowen et al. 1970). Huber et al. (1981), Daniel (1983) and more recently Desmecht et al. (1996) showed that ruminal and abomasal activity were severely altered during hypocal- 
caemia induced by $\mathrm{Na}_{2}$-EDTA infusion by measuring changes in intraruminal pressure.

Traditionally, measurement of rumen activity is obtained by placement of an intraruminally positioned pressure transducer for short term recordings of intraruminal pressure, as an indirect expression of rumen contractions (Bueno \& Fioramonti 1983). In this paper, we applied continous telemetric signal transfer of measurements of the rumen motility during altered concentration of blood calcium detected by strain gauge force transducers sutured on the rumen wall.

\section{Materials and methods}

A non-lactating, non-pregnant Jersey cow (350 $\mathrm{kg}$ ) was used. During the trials, the cow was fed on hay ad libitum. The strain gauge force transducer system for measurement of rumen motility was applied according to previous descriptions (Hara et al. 1996). Briefly, after local analgesia and under aseptic conditions a vertical $15 \mathrm{~cm}$ incision on the left paralumbal fossa was made, 4 strain gauge force transducers were sutured to the serosa of the dorsal rumen sac with $10 \mathrm{~cm}$ between each. Wires connecting the strain gauge force transducers were passed through a small incision and connected to a telemetric transmitter (DAS-800T, Star Medical Ltd., Tokyo, Japan) fixed dorsally on the lumbal area of the cow. The incision was closed with normal suturation technique. Recording was started 14 days after surgery. Signals were transmitted as radio signals, converted to analogue signals and plotted on a 4 channel plotter. All experiments were started with $30 \mathrm{~min}$ of measuring, to record the baseline level of motility of the rumen that particular day. No differences were found in baseline values with or without infusion of isotonic $\mathrm{NaCl}$ (data not shown). All experiments were started $2 \mathrm{~h}$ after morning feeding. Signals from the most dor- sally placed strain gauge force transducer showed superior signals of rumen motility compared to the 3 other strain gauge force transducers, and was therefore chosen to be the reference signal during the whole trial (Figs. $1 \&$ $2)$. Relative frequency of rumen contractions was measured at defined periods by counting the number of individual deviations from the baseline per min relative to the baseline value before the infusion started. Relative amplitude (strength) of the contractions was estimated by measuring average height of signals developed per min relative to baseline value.

Blood samples were taken from the coccygeal vessels with the Vacutainer ${ }^{\circledR}$ system in heparinized glasses. Free ionised calcium $(\mathrm{CaI})$ and potassium was measured cow-side by IRMA ${ }^{\circledR}$ transportable Blood Analysis System (Diametrics Medical, Minnesota, USA).

Experiment 1: Hypercalcaemia was induced in the normocalcaemic cow by the infusion of 400 $\mathrm{ml}$ calcium borogluconat containing $14 \mathrm{mg}$ calcium / $\mathrm{ml}$ through an i.v. catheter into $\mathrm{v}$. jugularis in approx 15 min similar to standard treatment of milk fever cows. The experiment was repeated after $24 \mathrm{~h}$.

Experiment 2: Hypocalcaemia was induced in the normocalcaemic cow by the infusion of a sterile $4.7 \% \mathrm{Na}_{2}$-EDTA (disodium ethylenetetraacetic acid) solution through an intravenous catheter into v. jugularis with an infusion speed of $10 \mathrm{ml} / \mathrm{min}$. Standard clinical observations were performed on the cow during infusion. Infusion was terminated when the cow was unable to stand. Shortly afterwards, the cow was infused with a standard dose of $400 \mathrm{ml}$ calcium borogluconate $(14 \mathrm{mg}$ calcium $/ \mathrm{ml})$. The experiment was repeated after 3 days.

\section{Results}

Experiment 1: Before calcium borogluconate infusion the cow was eating and ruminating 

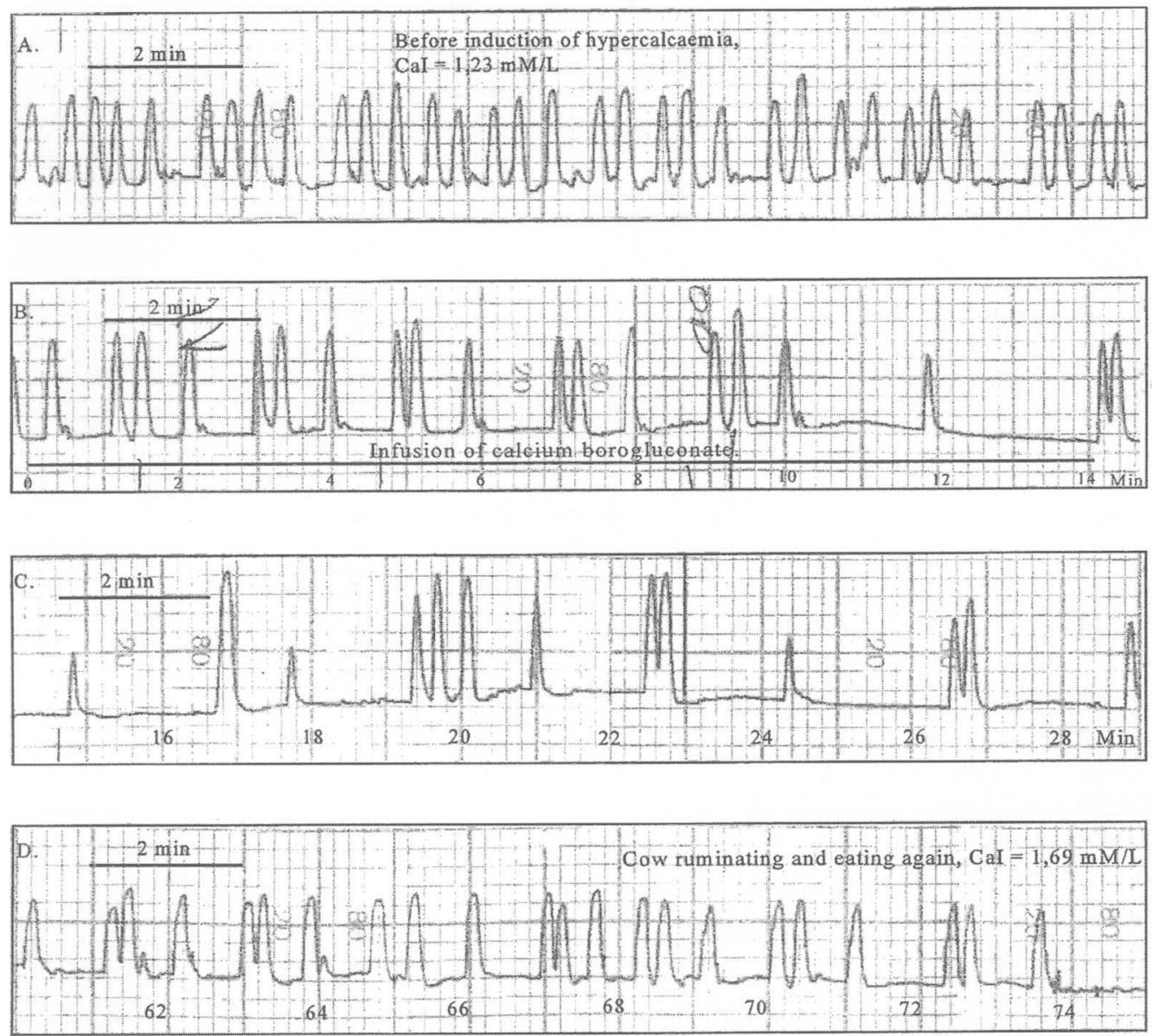

Figure 1. Induced hypercalcaemia and rumen motility. A: baseline level for rumen motility before induction of hypercalcaemia, $\mathrm{CaI}=1.23 \mathrm{mM} / \mathrm{L}$. B: Rumen contractions under calcium borogluconate infusion, muscle ticks and salivation developed. C: Rumen contractions after infusion. D: Rumen contractions when the cow started to ruminate and eat again, $\mathrm{CaI}=1.69 \mathrm{mM} / \mathrm{L}$.

normally. Rectal temperature and heart rate were within normal range. At the end of infusion eating and rumination ceased. Increased salivation and mild ticks were observed on the large muscle groups of the hind legs. Salivation and ticks disappeared after 30-40 min, and the cow started to ruminate and eat approx. $1 \mathrm{~h}$ after infusion. Rectal temperature remained unaltered, whereas the heart rate was lowered ap- prox. $20 \%$ (from 60 to $50 / \mathrm{min}$ ) up to $4 \mathrm{~h}$ after the infusion.

Hypercalcaemia developed after infusion of calcium borogluconate. Data from one experiment are shown in Fig. 1. At the end of infusion (CaI $2.7 \mathrm{mmol} / \mathrm{l}$ ), the frequency of rumen contractions was depressed $40 \%$ (Fig. 1B). A variation in amplitude of rumen contractions was seen after infusion although average amplitude 

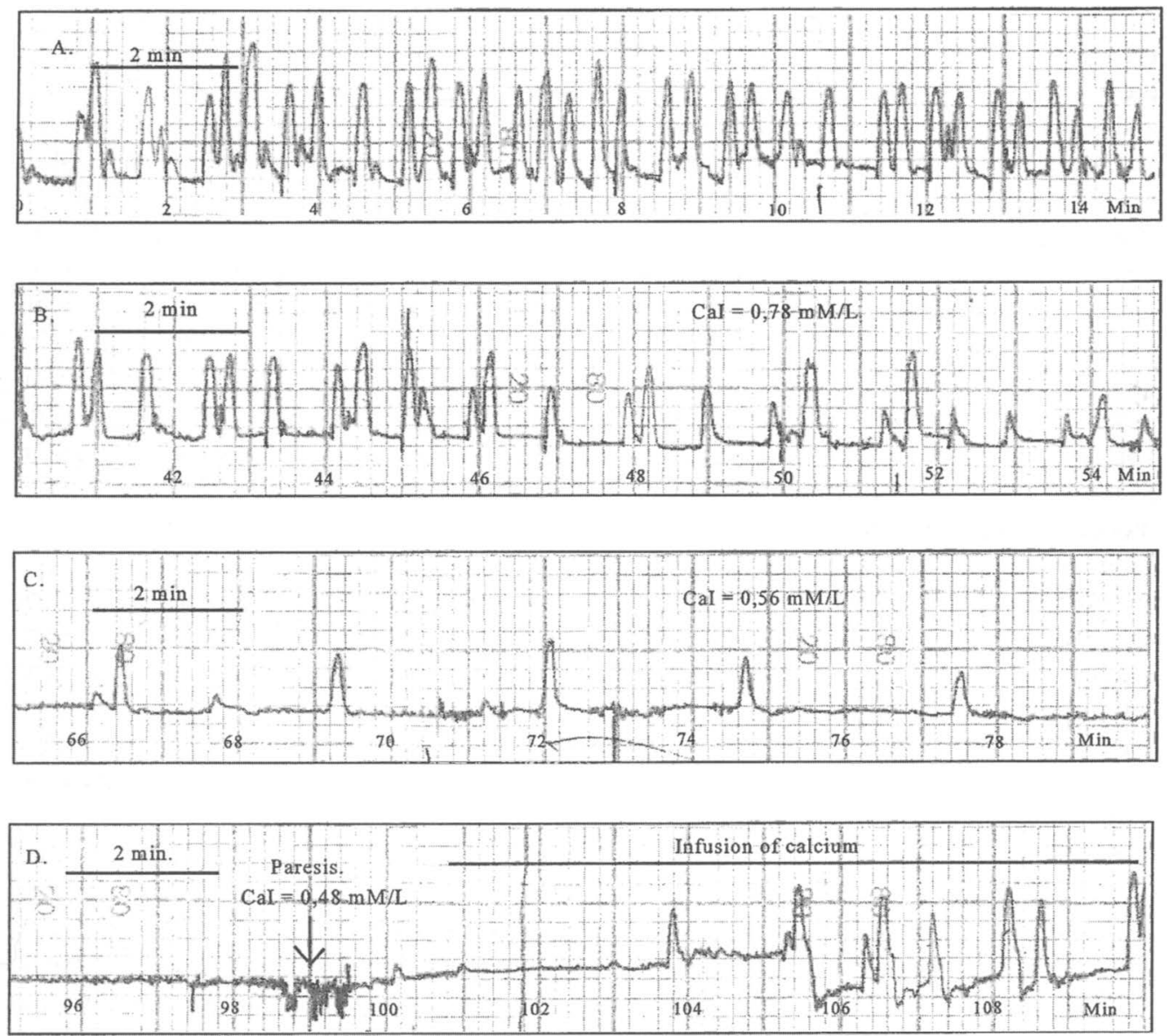

Figure 2. Rumen motility under induction of hypocalcaemia with the infusion of $\mathrm{Na}_{2}$-EDTA. A: Start of $\mathrm{Na}_{2}$-EDTA infusion at time $0 \mathrm{~min}, \mathrm{CaI}=1.29 \mathrm{mM} / \mathrm{L}$; B: Rumen motility at 40 to $55 \mathrm{~min}$ after start of infusion, cow still ruminating, $\mathrm{CaI}=0.78 \mathrm{mM} / \mathrm{L}$ at $50 \mathrm{~min} ; \mathrm{C}$ : Rumen motility at 65 to $80 \mathrm{~min}$ after start of infusion, mild tympanitis developed, no other clinical signs of hypocalcaemia, $\mathrm{CaI}=0.56 \mathrm{mM} / \mathrm{L}$ at $75 \mathrm{~min}$; $\mathrm{D}$ : Cow developing paresis at $99 \mathrm{~min}$ after start of infusion, $\mathrm{CaI}=0.48 \mathrm{mM} / \mathrm{L}$ at paresis. Rumen motility dramatically increased under calcium borogluconate infusion. The cow was standing up and eating again within $10 \mathrm{~min}$ after infusion of calcium borogluconate had been terminated.

remained similar to the baseline value (Fig. 1C). After approx $1 \mathrm{~h}$ the frequency of rumen contractions was again similar to the baseline value (Fig. 1D).

Experiment 2: During the infusion of $\mathrm{Na}_{2}$ EDTA, the cow became more and more hypocalcaemic as indicated by blood ionized calcium concentrations (Fig. 2). At an infusion speed of $10 \mathrm{ml} / \mathrm{min}$ the cow went down after 98 $100 \mathrm{~min}$, corresponding to the infusion of 132 $\mathrm{mg} \mathrm{Na}$-EDTA/kg BW. Initially, blood calcium decreased in a linear fashion and later a more slow decrease in $\mathrm{CaI}$ developed (data not shown). 
During the induced hypocalcaemia the cow gradually stopped eating and ruminating. After the cow stopped ruminating it looked depressed and later became atactic on the hind legs. Paresis developed at the interval $0.45-0.48 \mathrm{mmol} / 1$ CaI. Shortly after, the cow was infused with calcium borogluconate and responded by standing up and eating in less than $5 \mathrm{~min}$. The heart rate increased from base level as hypocalcaemia developed, and peaked around $80 / \mathrm{min}$ at paresis, corresponding to an increase of $40 \%$, but returned to baseline values shortly after calcium borogluconate infusion.

Rumen motility was severely altered during the induced hypocalcaemia (Fig. 2). At a CaI concentration of approx $0.8 \mathrm{mmol} / \mathrm{l}$, there was a clear depression in the frequency and amplitude of rumen contractions (Fig. 2B). At this time the cow showed no signs of milk fever. Later a mild tympanitis developed at $\mathrm{CaI}=0.56$ $\mathrm{mmol} / \mathrm{l}$ (Fig. 2C), although clinical signs of developing milk fever were still absent. Around 99 min, i.e., when the cow was unable to stand, rumen motility had ceased all together (Fig. 2D). The fluctuations of the baseline at this point indicate the falling cow. The effect of the therapeutic calcium borogluconate infusion on the hypocalcaemic cow was prompt: rumen contractions reappeared after few minutes of infusion, and were back to normal within 10 min after termination of calcium borogluconate infusion.

Rumen contractions in response to altered CaI concentration. In Fig. 3, the relative frequency and relative amplitude of rumen contractions are plotted as a function of $\mathrm{CaI}$ concentration during induced hyper- and hypocalcaemia. Clearly, hypocalcaemia influenced both frequency and amplitude of rumen contractions. From a CaI below $1.0 \mathrm{mmol} / \mathrm{l}$ a decrease in frequency and amplitude of rumen contractions developed. Between 0.7-0.9 mmol/1 CaI rumen motility was severely disturbed. At this calcium level, the cow showed no clinical signs of developing milk fever, and during this period the cow even ruminated now and then. At hypocalcaemia below $0.6 \mathrm{mmol} / 1 \mathrm{CaI}$ periods of total stasis occurred and below $0.55 \mathrm{mmol} / \mathrm{l} \mathrm{CaI}$ total stasis was permanent.

During hypercalcaemia, a decline in the frequency of rumen contractions was recorded, but no significant changes appeared in the amplitude. The decline in frequency during hypercalcaemia was up to $40 \%$ just after calcium borogluconate infusion (Fig. 1C). During the altered $\mathrm{CaI}$ concentration the level of potassium in blood was found to be within normal range.

\section{Discussion}

Recording of frequency and amplitude of rumen contractions during altered $\mathrm{CaI}$ concentrations by strain gauge force transducer implants and telemetric signal transfer (Itoh et al. 1977, Hara et al. 1996) appeared to be simple and allowed continuous precise and detailed recordings.

With the induction of hypocalcaemia by $\mathrm{Na}_{2}-$ EDTA infusion, the cow showed clinical signs similar to spontaneous milk fever but without additional clinical symptoms such as excessive salivation, tail lifting, increased movements of chewing muscles as reported by others (Fenwick \& Daniel 1990). Paresis developed at $0.45-0.48 \mathrm{mmol} / 1 \mathrm{CaI}$, which is similar to the $0.48 \pm 0.11 \mathrm{mmol} / 1 \mathrm{CaI}$ found in bulls by Desmecht et al. (1996). Paresis developed $80-100 \mathrm{~min}$ after infusion of $106-135 \mathrm{mg} \mathrm{Na}_{2}-$ $\mathrm{EDTA} / \mathrm{kg} \mathrm{BW}$, which is close to results obtained by Smith \& Brown (1963) and Muir et al. (1972).

Daniel (1983) demonstrated a linear relationship between plasma calcium and rumen contraction rates and amplitudes during induced hypocalcaemia in cows. Similarly Huber et al. (1981) found a linear relationship between amplitude of rumen contractions and decreasing 
A.

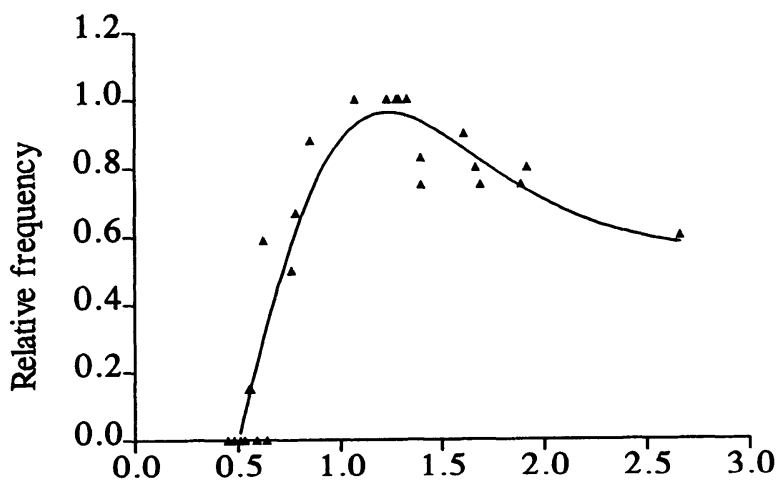

CaI concentration in blood, $\mathrm{mM} / \mathrm{L}$.

B.

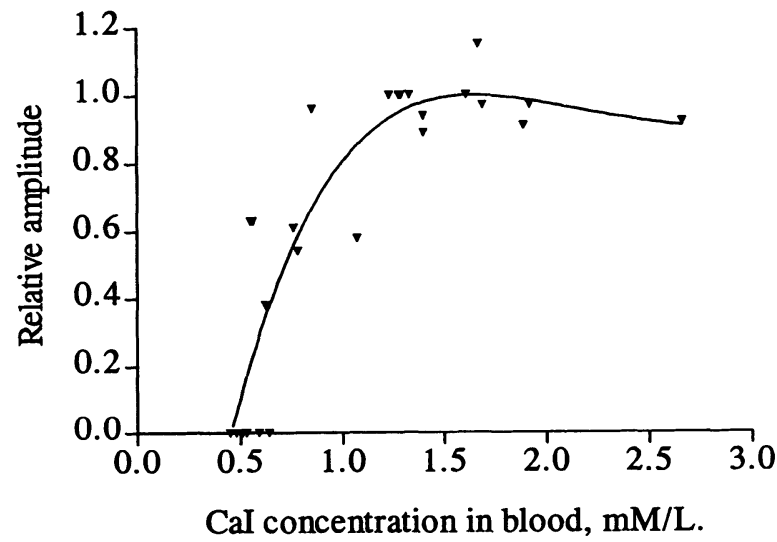

Figure 3. A: relative frequency and B: relative amplitude as a function of free ionized calcium (CaI) in blood. The relative frequency and amplitude is calculated as an $6 \mathrm{~min}$ average at blood sampling time for CaI measuring. Regression lines are computed by the Prism Program Packed (2.01) as a two composition model.

CaI in sheep. Different from our results, Daniel (1983) did not find complete stasis just before and under paresis, but a reduction in frequency and amplitude of rumen contractions of $33 \%$ and $43 \%$ respectively, at a concentration of total plasma calcium of $1.0 \mathrm{mmol} / \mathrm{l}$, which equals approximately the $0.55 \mathrm{mmol} / 1 \mathrm{CaI}$ found by Ballantine \& Herbein (1991). Recently Desmecht et al. (1996) working with bull calves showed a similar reduction in rumen contrac- tion rates and an average of $70 \%$ decrease in amplitude during hypocalcaemia at $\mathrm{CaI}$ of 0.64 $\pm 0.15 \mathrm{mmol} / \mathrm{l}$ compared to baseline level. Our continous recordings clearly show that frequency and amplitude of rumen contractions both decreased as hypocalcaemia developed, and that total stasis occurred below $0.53 \pm 0.06$ $\mathrm{mmol} / \mathrm{l} \mathrm{CaI}$. With a strain gauge force transducer method similar to ours, Madison \& Trout (1988) recorded continuously abomasal con- 
tractions with results much similar to our rumen recordings. They found an "all-or-none" value for abomasal contractions at a $\mathrm{CaI}$ concentration of $0.58 \pm 0.08 \mathrm{mmol} / \mathrm{l}$ (plasma calcium $=1.2 \pm 0.2 \mathrm{mmol} / \mathrm{l})$. Below this value no abomasal contractions occurred.

Similar to our results, Daniel (1981) and Desmecht et al. (1996) found that rumen motility could be severely altered although no clinical signs of developing milk fever were apparent. Having in mind that reduced gastrointestinal motility is a very significant factor for calcium absorption and thereby for the pathogenesis of milk fever (Hove \& Hilde 1984), the hypocalcaemic state may be self-aggrevating through reduced feed intake.

Hypercalcaemia is induced as a side effect to treatment or prevention of milk fever (Kvart et al. 1982, Goff et al. 1994). Dairy practitioneres are well aware that calcium infusions influence cardiac function and can cause cardiac arrest (Radostitis et al. 1994). In our experiments we observed bradycardia during hypercalcaemia, consonant to the studies of Littledike et al. (1976) who showed that bradycadia and ectopic ventricular beats were generated during induced hypercalcaemia in cows.

Hypercalcaemia depressed the frequency of rumen contractions in our study. A reduction in gastrointestinal smooth muscle excitability has also been recorded in dogs suffering from chronic hypercalcaemia due to Hyper-PTH release (Moreau \& Squires 1992). The present studies also showed that hypercalcaemia can alter rumen contraction rates. This finding is of therapeutic interest in normocalcaemic dairy cows since infusion of calcium salts is common practice in the treatment of downer cows or cows with non-specific indigestion. Contrary to the belief of many dairy practitioners, our results showed that calcium infusion therapy on a normocalcaemic cow had a negative influence on rumen motility.
In conclusion, the major finding of the present study, derived from the high sensitivity of the monitoring system, was the depression in frequency and amplitude of rumen contractions observed as early as $1.0 \mathrm{mmol} / \mathrm{l} \mathrm{CaI}$. Thus, rumen motility was affected far before any clinical signs of hypocalcaemia were observed, and while feeding behaviour and rumination still appeared unaltered. It strongly indicates that an unknown proportion of ruminating transition cows is likely to have severely depressed rumen motility due to hypocalcaemia. Health and production concequences are likely to be equally severe in these very stress vulnerable transition dairy cows.

\section{Acknowledgements}

This study was supported by the Danish Agricultural and Veterinary Research Council (grant no. 9600949).

\section{References}

Ballantin HT, Herbein JH: Potentiometric Determination of Ionized and Total Calcium in Blood Plasma of Holstein and Jersey Cows. J. Dairy Sci. 1992, 74, 446-449.

Bowen JM, Blackmon DM, Heavner JE: Neuromuscular transmission and Hypocalcemic Paresis in the Cow. Am. J. Vet. Res. 1970, 31, 831-839.

Bueno L, Fioramonti J: Dopaminergic control of gastro-intestinal motility. In: Ruckebusch Y, P.-L. Toutain P-L \& G.D. Koritz GD (eds.): Veterinary Pharmacology and Toxicology. AVI Publishing Company, Connecticut, 1983. pp 283-298.

Daniel RCW: Motility of the Rumen and Abomasum During Hypocalcaemia. Can. J. Comp. Med. 1983, 47, 276-280.

Desmecht DJ-M, Linden AS, Lekeux PM: Ruminal, Cardio-respiratory and Adrenocortical sequelae of $\mathrm{Na}_{2}$ EDTA-induced Hypocalcemia in Calves. Vet. Res. Comm. 1996, 20, 47-60.

Fenvick DC, Daniel RCW: A Comparison Between the Main Clinical Signs of Milk Fever in Cows with Those of Hypocalcaemia Induced by $\mathrm{Na}$ EDTA Solution. J. Vet. Med. A. 1990, 37, $721-728$.

Goff JP, Horst RL: Calcium Salts for Treating Hypocalcemia: Carrier Effects, Acid-Base Bal- 
ance, and Oral Versus Rectal Administration. J. Dairy Sci. 1994, 77, 1451-1456.

Hara S, Tamura T, Takahashi T, Kaneda Y, Tomizawa $N$, Okada $N$, Nishida M: Treatment Of Left Displaced Abomasum In Dairy Cows By The Combined Use Of alfa2-Adrenergic Drugs And Rolling. In: Poster Presentations, XIX World Buiatrics Congress, Edinburgh, 1996, Abstract nr. 110.

Hove $K$, Hilde BL: Plasma calcium in the lactating cow: Dependence on continuous intestinal absorption. Can. J. Anim. sci. 1984, Suppl. 64, 227 228.

Huber TL, Wilson RC, Stattelman AJ, Goetsch DD: Effect of Hypocalcemia on Motility of the Ruminant Stomach. Am. J. Vet. Res. 1981, 42, 14881490.

Itoh Z, Honda R, Takeuchi S, Aizawa I, Takayanagi $R$ : An extraluminal force transducer for recording contractile activity of the gastrointestinal smooth muscle in conscious dogs; Its construction and implantation. Gastroent. Jpn. 1977, 12, 275-283.

Kvart C, Bjørsell KA, Larsson L: Parturient paresis in the cow. Acta. vet. scand. 1982, 23, 184-196.

Littledike ET, Glazier D, Cook HM: Electrocardiographic Changes After Induced Hyper-calcemia and Hypocalcemia in Cattle: Reversal of the Induced Arrhytmia with Atropine. Am. J. Vet. Res. 1976, 37, 383-388.

Madison JB, Troutt HF: Effects of hypocalcaemia on abomasal motility. Res. Vet. Sci. 1988, 44, 264266.

Moreau $R, \&$ Squires RA: Hypercalcemia. Compend. Contin. Educ. Pratc. Vet. 1992, 14, 1077-1081.

Muir LA, Hibbs JW, Conrad HR, Smith KL: Effect Of Estrogen and Progesterone on Feed Intake and Hydroxyproline Excretion Following Induced Hypocalcemia in Dairy Cows. J. Dairy Sci. 1972, 55, 1613-1620.

Navarre CB, Roussel AJ: Gastrointetinal Motility and Diseases in Large Animals. Jour. Vet. Intern. Med. 1996, 20, 51-59.

Radostitis OM, Blood DC, Gay CC: Metabolic Diseases. In: Veterinary Medicine; A Textbook of the Diseases of Cattle, Sheep, Pigs, Goats and Horses. Bailliere Tindall, London, 1994 eighth Edition. pp 1310-1367.

Rosol TJ, Chew DJ, Nagode LA, Capen CC: Pathophysiology of Calcium Metabolism. Vet. Clin. Patho. 1995, 24, 49-63.

Smith VR, Brown WH: Response of some blood constituents to infusions of disodium ethylenediamine tetraacetate in intact cattle. J. Dairy Sci. $1963,46,223-226$.

\section{Sammendrag \\ Vommotilitet under induceret hyper- og hypocal- caemi.}

Vommotilitet er under eksperimentelle forhold målt på en ko vha. telemetrisk signaloverførsel fra strækkereceptorer kirurgisk anbragt på vommens bughinde $\mathrm{i}$ venstre flanke. Hypercalcæmi blev induceret på den normocalcæmiske ko ved infusion af calcium borogluconate $(400 \mathrm{ml} 14 \mathrm{mg} \mathrm{Ca} / \mathrm{ml})$ intravenøst. Kliniske tegn umiddelbart efter infusionen var nedsat drøvtygning, muskelsitren, øget salivation og en reduktion i hjertefrekvensen på $20 \%$. Rektaltemperaturen forblev uændret. Vomkontraktionernes frekvens blev reduceret med op til $40 \%$ efter infusionen, hvorimod vomkontraktionernes amplitude ikke afveg fra udgangsniveauet. Hypocalcæmi blev induceret $i$ et efterfølgende eksperiment via iv infusion af $\mathrm{Na}_{2}$ EDTA. Ved $0,60 \mathrm{mmol} / 1$ ioniseret blodcalcium kunne perioder med manglende vommotilitet forekomme, mens vommotiliteten var totalt ophørt ved en koncentration af blodets fri ioniseret calcium på $0,55 \mathrm{mmol} / 1$. Ved en koncentration af fri ioniseret blodcalcium på 0,45-0,48 mmol/1 blev koen paretisk og hjertefrekvensen steg med $40 \%$. Den høje sensivitet af den anvendte metode tillod konklusionen, at allerede ved en koncentration af blodets fri ioniserede calcium på $1,0 \mathrm{mmol} / \mathrm{l}$ blev både vomkontraktionernes frekvens og amplitude nedsat betydeligt $i$ forhold til udgangsværdien, selvom ædeadfærd og drøvtygning virkede upåvirket på kort sigt. Betydningen heraf for kælvekøers sundhed og produktion diskuteredes.

(Received January 1998; accepted January 10, 1998).

Reprints may be obtained from: R.J. Jørgensen, Cattle Research Group, Department of Clinical Studies, Royal Veterinary and Agricultural University, Bülowsvej 13, DK-1870 Frederiksberg C, Denmark. E-mail: rjj@kvl.dk, tel: +45352828 36, fax: +4535282838. 